\title{
Fatty Acid Composition, Acetylcholinesterase and Bacterial Inhibition by Inga cinnamomea Pulp
}

\author{
Herliana Damelys Flores Abreu ${ }^{1}$, Antonio Alves de Melo Filho ${ }^{1,3,6}$, Pedro Rômulo Estevam Ribeiro2, \\ Bernardo de Morais Linhares ${ }^{1}$, Maria da Conceição Freitas Campêlo ${ }^{1}$, Jacqueline Aparecida Takahashi ${ }^{4}$, \\ Debora Luiza Costa Barreto ${ }^{4}$, Nathália Barroso Almeida Duarte ${ }^{4}$, Vany Perpetua Ferraz ${ }^{5}$ \\ \& Habdel Nasser Rocha da Costa ${ }^{1,6}$ \\ ${ }^{1}$ Postgraduate Program in Chemistry, Federal University of Roraima, Campus Paricarana, Boa Vista, RR, Brazil \\ ${ }^{2}$ Postgraduate Program in Natural Resources, Federal University of Roraima, Campus Paricarana, Boa Vista, RR, \\ Brazil \\ ${ }^{3}$ Postgraduate Program in Biotechnology and Biodiversity, Federal University of Roraima, Campus Paricarana, \\ Boa Vista, RR, Brazil \\ ${ }^{4}$ Department of Chemistry, Institute of Exact Sciences, Federal University of Minas Gerais, Belo Horizonte, \\ Minas Gerais, MG, Brazil \\ ${ }^{5}$ Chromatography Laboratory, Institute of Exact Sciences, Federal University of Minas Gerais, Belo Horizonte, \\ Minas Gerais, MG, Brazil \\ ${ }^{6}$ Departament of Chemitry, Federal University of Roraima, Campus Paricarana, Boa Vista, RR, Brazil \\ Correspondence: Herliana Damelys Flores Abreu, Postgraduate Program in Chemistry, Center for Research and \\ Graduate Studies in Science and Technology, Campus Paricarana, CEP 69304-000, Boa Vista, RR, Brazil. E-mail: \\ hhherliana@gmail.com
}

Received: November 1, 2017

Accepted: December 14, 2017 Online Published: January 15, 2018

doi:10.5539/jas.v10n2p281

URL: https://doi.org/10.5539/jas.v10n2p281

\begin{abstract}
Inga cinnamomea, a species from Fabaceae family, posses a convex-cylindrical fruit that has a white, slightly sweet, edible pulp, which is very appreciated in Brazil. The present study seeks to expand the knowledge about this fruit. The vegetable oil of the fruit's pulp, extracted in a Soxhlet extractor using hexane as solvent, was studied. Fatty acids were determined, after oil hydrolysis and methylation, using gas chromatography with flame ionization detector (GC-FID). Additionally, the oil was tested to determine its potential as acetylcholinesterase inhibitor using Eserine as positive control. Bactericidal potential of the oil was also determined. Both assays were accomplished using Elisa spectrophotometer. Eight major fatty acids were detected in the following concentrations: linoleic $(\omega 6)(31.7 \%)$, palmitic $(26.2 \%)$, linolenic $(\omega 3)(13.6 \%)$, oleic $(\omega 9)(12.5 \%)$, stearic $(6.5 \%)$, palmitoleic $(\omega 7)(2.0 \%)$, myristic $(0.6 \%)$ and arachidic $(0.6 \%)$ acids. The oil inhibitory activity towards acetylcholinesterase enzyme was $54.81 \%$, being classified as a potent effect. Finally, the oil presented a modest inhibitory activity against the following bacterial strains: Staphylococcus aureus (24.68\%), Citrobacter freundii (20.46\%), Listeria monocytogenes (27.26\%) and Pseudomonas aeruginosa (26.89\%).
\end{abstract}

Keywords: Inga cinnamomea, fabaceae, oil, acetylcholinesterase, fatty acid

\section{Introduction}

Inga cinnamomea is a plant species from Fabaceae family, genus Mimosa. Inga cinnamomea is commonly known as ingá açu, ingá pracuuba, ingá chinelo and ingá guaçu in Amazonas (Brazil) (Peningtong, 1997). The importance of legumes in the world is due, mostly because of the content of proteins and minerals in their seeds, many of them for human and animal consumption (Smith et al., 2004; Heywood et al., 2007). It is also important their ability of enriching nutrient-poor soils by fixing nitrogen in symbioses with Rhizobium bacteria (Smith et al., 2004; Heywood et al., 2007; Kurppa et al., 2010; Remigi et al., 2016; Montandon et al., 2010; Grossman et al., 2006; Franco \& Faria, 1997).

Particularly, the ingá trees are distributed throughout the world within the Bolivian Amazon, Peru, Equador, Colombia, extending within the Brazilian Amazon (Peningtong, 1997). In Mexico were reported the presence of 
the following ingá species I. alba, I. densiflora, I. multijuga, I. oerstediana, I. paterno, I. ruiziana, I.vera, I. bella, I. cabrerae, I. calcícola, I. cuspidata, I. chiapensis, I. dasycarpa, I. davidsei, I. dwyeri, I. ismaelis, I. lacustris, I. pseudoinvolucrata, I. sinacae, I. tenella (Sousa, 1993). While in Brazil, the most common species are I. cylindrica, I. laurina, I. marginata, I. edulis, I. vera, and I. cinnamomea (Lorenzi, 2002). From them, only a few have been studied so far.

Between the species of ingá already studied, stand out the species I. edulis and I. laurina. It has been determined that the hydroalcoholic extract of I. edulis leaves has antinociceptive, anti-inflammatory, antiulcerogenic activity (Pompeu et al., 2012), as well as antioxidant, photoprotective and anti-inflammatory potential to the skin (Costa, 2015). The antioxidant activity of $I$. edulis leaves has been tested in several studies, showing high activity (Pompeu et al., 2012; Sousa et al., 2010; Sousa et al., 2007). It is also active in cancer prevention (Yang et al. 2001), has ability to inhibit specific enzymes, simulate some hormones or neurotransmitters, and eliminate free radicals (Havsteen, 2002). Additionally, from the fresh pulp of the I. edulis fruit, was extracted a peroxidase enzyme that has been used as a biosensor to quantify the antioxidant terc-butylhydroquinone (TBHQ) in food (Oliveira et al., 2014).

On the other hand, from the I. laurina seeds was extracted a Kunitz inhibitor called ILTI (Inga laurina Trypsin Inhibitor) (Macedo et al., 2007). It showed insecticidal activity against Diatraea saccharalis, Heliothis virescens (Ramos et al., 2012) and Homalinotus coriaceus (Macedo et al., 2011). This inhibitor also showed antimicrobial activity, especially against Candida tropicalis and Candida buinensis (Macedo et al., 2016). Besides, from the I. laurina seeds was extracted a new triterpenoid saponin named "ingasaponin", a component with immunological adjuvant activity as well as a significant hemolytic potential (Cruz et al., 2016). Therefore, ingá species present a great potential for several uses. In that sense, this work expects to contribute with the scientific knowledge on $I$. cinnamomea species, in order to point out new potentialities or significant properties to be further exploited.

Inga cinnamomea is yellow-green and convex-cylindrical fruit at maturity. In average, the seeds of $I$. cinnamomea measure $4 \times 1.5 \times 1.3 \mathrm{~cm}$ (Peningtong, 1997), have pleurogram (Smith et al., 2004), and are surrounded by a white pulp, slightly sweet, edible and very appreciated by the population (Galvão, 2005). I. cinnamomea pulp has been poorly studied, what motivates the accomplishment of this work. Nevertheless, it was reported that I. cinnamomea's pulp is a source of minerals like $\mathrm{Mg}, \mathrm{Na}, \mathrm{P}, \mathrm{Mn}, \mathrm{Fe}$, and $\mathrm{Zn}$ (Berto et al., 2015). Regarding the chemical composition of I. cinnamomea's fruits pulp, it was reported the presence of volatile constituents such as methyl linoleate, chenopodiol, ethyl hexadecanoate and heptacosane (Silva et al., 2012). Also, several fatty acids have been reported in the pulp of this ingá, the more abundant being linoleic, palmitic, linolenic and oleic acids (Berto et al., 2015).

The objective of this study was to verify the fatty acid profile of the vegetable oil from the pulp of Inga cinnamomea, as well as to analyze the acetylcholinesterase and bacteria growth inhibition effect exerted by this oil.

\section{Method}

\subsection{Identification of the Species and Obtaining the Fruit}

The species was identified using a voucher specimen deposited in the Integrated Museum of Roraima (MIRR: 13654). Later the fruits were collected in Asa Branca neighborhood, Boa Vista, Roraima (lat: 2.81132; long: 60.720779).

Mature fruits with good physical appearance were collected and taken to the Environmental Chemistry Laboratory at the Federal University of Roraima, Boa Vista, Brazil.

\subsection{Oil Extraction from Inga cinnamomea Pulp}

Fruits were cleaned, and the pulp was separated from the peel and the seeds. Thereafter, the pulp was dried at $50{ }^{\circ} \mathrm{C}$ for $72 \mathrm{~h}$. Dried pulp was ground, and the powder sieved with a 20-40 Mesh sieve. The vegetable oil obtained from the pulp was extracted using hexane as extraction solvent in a Soxhlet extractor for $3 \mathrm{~h}$. It was done in triplicate and the oil was stored in amber bottles under nitrogen atmosphere and stored in a freezer (Fernández et al., 2016; Santos et al., 2015; Jorge \& Luzia, 2012).

\subsection{Hydrolysis and Methylation of Inga cinnamomea Vegetable Oil for Chromatographic Analysis}

Hydrolysis was carried out using $12 \mathrm{mg}$ of the oil sample in $100 \mu \mathrm{L}$ of ethanol $(95 \%)$ /potassium hydroxide 1 mol $\mathrm{L}^{-1}(5 \%)$ solution. After vortexing for $10 \mathrm{~s}$, the oil was hydrolyzed in a domestic microwave oven (Panasonic NN-ST254W) at $60 \%$ power $(420 \mathrm{~W})$ during 6 minutes. After cooling, were added $400 \mu \mathrm{L}$ of hydrochloric acid $20 \%, \mathrm{NaCl}(\sim 20 \mathrm{mg})$ and $600 \mu \mathrm{L}$ of ethyl acetate. After vortexing for further $10 \mathrm{sec}$ and standing for $5 \mathrm{~min}$, an 
aliquot $(300 \mu \mathrm{L})$ of the organic layer was removed, placed in microcentrifuge tubes and dried by evaporation, thus obtaining the free fatty acids (Christie, 1989). Subsequently, the free fatty acids were methylated with 100 $\mu \mathrm{L} \mathrm{BF}_{3} /$ methanol (14\%), $\mathrm{BF}_{3}$ being the reaction catalyst. The mixture was heated for 10 minutes in at $60{ }^{\circ} \mathrm{C}$ water bath. The methylated fatty acids were extracted with $500 \mu \mathrm{L}$ of hexane and analyzed by Gas Chromatography.

\subsection{Determination of Fatty Acids by Gas Chromatography with Flame Ionization Detector (GC-FID)}

The analyses were performed on a Gas Chromatograph HP7820A (Agilent) equipped with a flame ionization detector. Data Acquisition Program used was EZChrom Elite Compact (Agilent). It was used a Supelcoxax column $\left[15 \mathrm{~m} \times 0.2 \mathrm{~mm} \times 0.2 \mu \mathrm{m}\right.$ (Supelco)] with temperature gradient: $120^{\circ} \mathrm{C}, 0 \mathrm{~min}, 7^{\circ} \mathrm{C} \mathrm{min}^{-1}$ to $240{ }^{\circ} \mathrm{C}$; Injector $(1 / 50$ split $)$ at $250{ }^{\circ} \mathrm{C}$ and detector at $260{ }^{\circ} \mathrm{C}$. Hydrogen was used as mobile phase at a rate of $3.0 \mathrm{~mL}$ $\mathrm{min}^{-1}$. The volume of injection was $1 \mu \mathrm{L}$ and peak identification was accomplished by comparison with methylated fatty acid standards Supelco37 Fame mix (Supelco cat no 47885-U) (Christie, 1989).

\subsection{Acetylcholinesterase Inhibition Assay}

A sample working solution $\left(10 \mathrm{mg} \mathrm{mL}^{-1}\right)$ was prepared in DMSO. Then, $25 \mu \mathrm{L}$ of this working solution was added to the wells of an Elisa plate. In addition, negative and positive controls were prepared. Eserine was used as positive control. In the first five wells of the positive control column, were added $25 \mu \mathrm{L}$ of Eserine solution (10 mg mL ${ }^{-1}$ in Tris/HCl; $\mathrm{pH} 8.0$ buffer), and $25 \mu \mathrm{L}$ DMSO. To each well, were added $25 \mu \mathrm{L}$ of acetylcholineiodide iodide (ATCI), $125 \mu \mathrm{L}$ of DTNB solution (5',5-dithio-bis-(2-nitrobenzoate, Sigma) and 50 $\mu \mathrm{L}$ Tris $/ \mathrm{HCl} 50 \mathrm{mM}$ ) with bovine serum albumin. The absorbance was measured at $405 \mathrm{~nm}$ every $1 \mathrm{~min}, 8$ times (8 min in total). Then, $25 \mu \mathrm{L}$ of the AChE electric eel solution $\left(0.222 \mathrm{U} \mathrm{mL}^{-1}\right)$ in Tris/HCl were added to each well. The absorbance at $405 \mathrm{~nm}$ was measured 10 times (10 min in total) in a microplate reader (Ellman et al., 1961; Frank \& Grupta, 2005).

\subsection{Bacteria Inhibition Assay}

For the bioassay of inhibitory microbial activity, in first place a pre-inoculum was prepared. Therefore, $3.0 \mathrm{~mL}$ of BHI (Brian heart infusion) culture medium was placed in test tubes and then the bacteria were transferred into these test tubes using a platinum loop. The tubes were incubated in an oven at $37{ }^{\circ} \mathrm{C}$ for $36 \mathrm{~h}$. Using a micropipette, $200 \mu \mathrm{L}$ of this pre-inoculum were transferred to test tubes containing sterile distilled water. The bacteria used were: Listeria monocytogenes (ATCC 15313), Staphylococcus aureus (ATCC29212), Citrobacter freundii (ATCC8090) and Pseudomonas aeruginosa (ATCC27853).

In order to obtain the inocula used in the bioassay, the aforementioned tubes were homogenized and then absorbances of the solutions were read in an Elisa spectrophotometer. The concentration of the inocula was adjusted at $600 \mathrm{~nm}$, until reach a transmittance reading between $74-75 \%$, corresponding to $10^{8}$ cells $\mathrm{mL}^{-1}$ or 0.5 turbidity according to the McFarland standard turbidity scale. The pulp oil sample was solubilized in dimethylsulfoxide (DMSO) obtaining a solution with concentration of $12.5 \mathrm{mg} \mathrm{mL}^{-1}$. Then, $40 \mu \mathrm{L}$ of this solution were added to $960 \mu \mathrm{L}$ of culture medium to prepare the working solution.

The bioassays were run in 96 micro wells in triplicate. In the well 1 (test) were added $100 \mu \mathrm{L}$ of the working solution and $100 \mu \mathrm{L}$ of standardized inoculum. In well 2 were added $100 \mu \mathrm{L}$ of culture medium and $100 \mu \mathrm{L}$ of standardized inoculum for growth control of the microorganism. In well 3 were added $100 \mu \mathrm{L}$ of culture medium and $100 \mu \mathrm{L}$ of sterile distilled water. The positive control was performed in well 4 , replacing the working solution with the antibiotic ampicillin. The sterility control of the culture medium was made in well 5 , containing $100 \mu \mathrm{L}$ culture medium and $100 \mu \mathrm{L}$ of sterile distilled water. The microplates were incubated in an incubator at $37^{\circ} \mathrm{C}$ and, after $24 \mathrm{~h}$, results reading was performed in an Elisa type reader (600 nm) (Santos et al., 2015).

\section{Results and Discussion}

\subsection{Fatty Acids Determination and Quantification by Gas Chromatography Using Flame Ionization Detector (GC-FID) and Yield of Oil in I. cinnamomea Pulp}

Extraction with hexane from I. cinnamomea pulp yielded $0.42 \%$ of vegetable oil. In contrast, Berto et al. (2015) reported a yield of $0.08 \%$, a lower yield of vegetable oil compared to the result found in this research. This discrepancy is probably due to the differences in the methodology used in both researches, since a different solvent (Choroform) and a different extraction methodology was utilized. Analysis of the oil with GC-FID detected eight fatty acids, as shown in the chromatogram presented in Figure 1. 


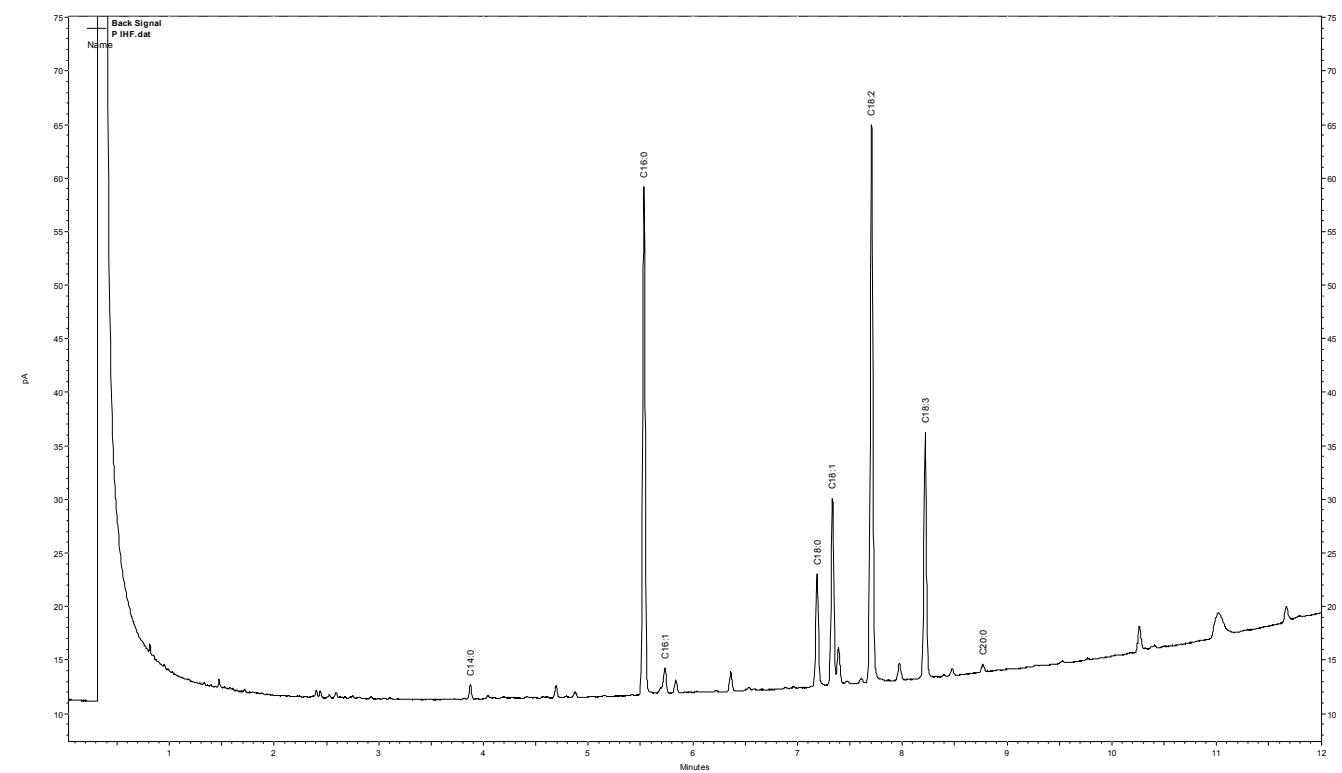

Figure 1. Fatty Acids Chromatogram of I. cinnamomea cinnamomea pulp

In Table 1 is presented a list of the fatty acids found, together with their respective concentration (\%) compared to data reported in the literature.

Our results show that, in this oil, polyunsaturated fatty acids predominate, representing $45.3 \%$ of the total, whereas the saturated ones represent $33.9 \%$ and the monounsaturated form $14.5 \%$ of the total content. It is possible to note that the more abundant fatty acids in this oil are linoleic $(\omega 6)(31.7 \%)$, palmitic $(26.2 \%)$, linolenic $(\omega 3)(13.6 \%)$ and oleic $(\omega 9)(12.5 \%)$.

Linoleic (18:2 $\omega 6)$ and linolenic acids (18: $3 \omega 3)$ are essential acids but cannot be synthesized by human body. These are required to maintain cell membranes under normal conditions (Food Ingredients Brazil, 2016; Strayer et al., 2016), brain functions and are necessary for transmission of nerve impulses, among many other functions (Food Ingredients Brazil, 2016). Lack of linolenic acid ( $\omega 3)$ has been associated with neurological abnormalities and poor growth (Strayer et al., 2016).

Omega 3 fatty acid can help improving concentration and memory. Omega 3 and 9 fatty acids are related to healthier triglyceride levels, and decreased levels of total cholesterol in blood (Food Ingredients Brazil, 2016).

The polyunsaturated and monounsaturated acids which predominate in this oil do not form fatty deposits that black the arteries, as occurs with saturated fatty acids (Food Ingredients Brazil, 2016). Other fatty acids found in the oil, at a lower concentration, were stearic $(6.5 \%)$ and palmitoleic $(\omega 7)(2.0 \%)$ acids, with myristic and arachidic acids both being present in still smaller quantities $(0.6 \%)$.

Fatty acids found in this research correspond quite well with previous report found in the literature for $I$. cinnamomea (Table 1). However, some differences in concentrations of fatty acids were observed when comparing the results of this study with those reported by Berto et al. (2015). The differences were more noticeable for palmitoleic, oleic, linoleic and linolenic acids, but were never higher than $4 \%$.

Since these fatty acids were quantified in plants grown in different states of Brazil, the differences in oil quantities may result in the different influences of environmental factors (Crowley \& Fröhlich, 1998; Francis \& Campbell, 2003).

In addition, the oils were extracted using different methodologies, including different extraction solvent, chloroform (Berto et al., 2015) vs hexane, which could also have influenced the final quantification of fatty acids. 
Table 1. Fatty acids in vegetable oil from I. cinnamomea pulp compared to literature data

\begin{tabular}{|c|c|c|c|c|}
\hline \multirow[t]{2}{*}{ Fatty Acid } & \multirow[t]{2}{*}{ RT (min) } & $\begin{array}{l}\text { I. cinnamomea } \\
\text { Current study }\end{array}$ & $\begin{array}{l}\text { I. cinnamomea (Ingá açu) } \\
\text { (Berto et al., 2015) }\end{array}$ & $\begin{array}{l}\text { Hymenaea courbaril (Jatobá) } \\
\text { (Dias et al., 2013) }\end{array}$ \\
\hline & & $\%$ & $\%$ & $\%$ \\
\hline Myristic (C14:0) & 3.881 & 0.6 & 0.7 & 0.2 \\
\hline Palmitic (C16:0) & 5.558 & 26.2 & 27.2 & 25.1 \\
\hline Palmitoleic $(\omega 7)(\mathrm{C} 16: 1)$ & 5.687 & 2.0 & 3.5 & 1.8 \\
\hline Stearic (C18:0) & 7.236 & 6.5 & 5.7 & 3.1 \\
\hline Oleic $(\omega 9)(\mathrm{C} 18: 1)$ & 7.432 & 12.5 & 8.9 & 46.1 \\
\hline Linoleic $(\omega 6)(\mathrm{C} 18: 2)$ & 7.748 & 31.7 & 35.0 & 8.6 \\
\hline Linolenic $(\omega 3)(\mathrm{C} 18: 3)$ & 8.223 & 13.6 & 10.6 & 14.5 \\
\hline Arachidic (C20:0) & 8.924 & 0.6 & 0.4 & 0.6 \\
\hline Other & - & 6.4 & 8.0 & - \\
\hline Total & - & 100 & 100 & 100 \\
\hline Saturated Fatty Acids & - & 33.9 & 34.0 & 29.0 \\
\hline Monounsaturated Fatty Acids & - & 14.5 & 12.4 & 47.9 \\
\hline Polyunsaturated Fatty Acids & - & 45.3 & 45.6 & 23.1 \\
\hline
\end{tabular}

In Table 1, the results of the fatty acid content in the I. cinnamomea pulp are also compared with the results obtained for $H$. courbaril pulp, known as Jatobá, a plant that also belongs to the Fabaceae family. The fruit contains a floury, yellowish and smelly pulp, which is consumed as food in several countries (Flores \& Benavides, 1990).

When comparing the results of the pulps of these two fruits belonging to the same family, a similar percentage of fatty acids was observed. A notorious difference was found concerning to oleic $(\omega 9)$ and linoleic $(\omega 6)$ acids. The concentration of oleic acid ( $\omega 9)$ in the I. cinnamomea pulp is $12.5 \%$ whereas for $H$. courbaril it is $46.1 \%$, being more concentrated in the species $H$. courbaril. At the same time, the concentration of linoleic acid $(\omega 6)$ in $I$. cinnamomea was $31.7 \%$ whereas for $H$. courbaril it was $8.6 \%$. Also, I. cinnamomea has been found to have triple the amount of stearic acid than $H$. courbaril. Palmitic acid was one of the major constituents in both species and also was found in similar concentrations. Other fatty acids found in similar concentrations in both species were myristic, palmitoleic, linolenic and arachidic acids.

As result of the differences in fatty acids concentrations in these species, I. cinnamomea has a higher concentration of polyunsaturated acids, whereas $H$. courbaril has a higher percentage of monounsaturated acids.

\subsection{Acetylcholinesterase Inhibition of Vegetable Oil from I. cinnamomea Pulp}

Acetylcholine is a neurotransmitter involved in memory and association processes (Flores \& Segura, 2003). Increasing the concentration of acetylcholine in the brain by modulating the activity of the enzyme acetylcholine esterase (AChE) is one of the most promising therapeutic strategies to improve cognitive function in patients with Alzheimer's disease (Pakaski \& Kasa, 2003; Trevistan et al., 2003), since this enzyme terminates the neurotransmission mediated by acetylcholine, hydrolyzing it (Soreq \& Seidman, 2001).

The vegetable oil of $I$. cinnamomea pulp inhibited acetylcholinesterase enzyme in $54.81 \%$, as shown in Table 2 .

Table 2. Acetylcholinesterase inhibition of vegetable oil from I. cinnamomea pulp

\begin{tabular}{ll}
\hline Sample & \% Inhibition \\
\hline I. cinnamomea Oil Pulp & $54.81 \pm 0.79$ \\
Positive control: Eserine & $92.93 \pm 0.10$ \\
\hline
\end{tabular}

This percentage of inhibition is considered potent, according to the classification given by Vinutha et al. (2007) in which any result greater than $50 \%$ is considered potent, values between $30-50 \%$ of inhibition are considered moderate, and below $30 \%$ are considered weak inhibitions. Therefore, vegetable oil from I. cinnamomea pulp has potential to be studied for therapeutic purposes to treat Alzheimer's disease.

\subsection{Bacteria Inhibition of Vegetable Oil from I. cinnamomea Pulp}

In Table 3 are presented the results of growth inhibition of bacteria S. aureus, C. freundii, L. monocytogenes, P. aeruginosa using the vegetable oil from I. cinnamomea pulp. As can be observed, inhibition of these bacteria 
growth was poor compared to the positive control used (Ampicillin), nevertheless a certain inhibition was observed. The importance of inhibiting the growth of these bacteria relies in the severity of some diseases and infections that these bacterial species can cause.

Table 3. Bacteria inhibition of vegetable oil from I. cinnamomea pulp

\begin{tabular}{lll}
\hline Bacteria & \% Inhibition I. cinnamomea & \% Inhibition Ampicillin \\
\hline S. aureus & $24.68 \pm 1.98$ & $94.64 \pm 0.62$ \\
C. freundii & $20.46 \pm 1.88$ & $94.51 \pm 0.55$ \\
L. monocytogenes & $27.26 \pm 1.25$ & $94.65 \pm 0.73$ \\
P. aeruginosa & $26.89 \pm 0.12$ & $94.64 \pm 0.74$ \\
\hline
\end{tabular}

Listeria monocytogenes produces a disease called Listeriosis. Some of the symptoms of this infection are diarrhea and fever. Staphylococcus aureus can produce enterotoxins that cause the symptoms of food poisoning, can cause infection in wounds, and are a common cause of post-surgical infections (Pelczar \& Krieg, 2010). Pseudomonas aeruginosa also causes hospital infections. An initial localized infection may lead to invasion of the circulatory system. In a patient with cystic fibrosis, microorganisms often cause severe and fatal pneumonia (Pelczar \& Krieg, 2010). Finally, Citrobacter freundii causes a variety of infections in the elderly, immunocompromised, and debilitated patients (Wang et al., 2000). Cases of meningitis caused by this bacterium have been reported (Tang et al., 1994).

\section{Conclusion}

The vegetable oil of I. cinnamomea pulp is constituted by eight major fatty acids, detected in the following concentrations: linoleic $(\omega 6)(31.7 \%)$, palmitic $(26.2 \%)$, linolenic $(\omega 3)(13.6 \%)$, oleic $(\omega 9)(12.5 \%)$, stearic, palmitoleic $(\omega 7)(2.0 \%)$, myristic $(0.6 \%)$ and arachidic $(0.6 \%)$ acids. This oil has also a potent inhibitory activity $(54.81 \%)$ of the enzyme acetylcholinesterase, a feature that can be exploited in the future for therapeutic use in Alzheimer's disease. Finally, a discrete bactericidal inhibition of this oil was determined on the bacteria Staphylococcus aureus (24.68\%), Citrobacter freundii (20.46\%), Listeria monocytogenes (27.26\%) and Pseudomonas aeruginosa (26.89\%).

\section{References}

Berto, A., Da Silva, A. F., Visentainer, J. V., Matsushita, M., \& de Souza, N. E. (2015). Proximate compositions, mineral contents and fatty acid compositions of native Amazonian fruits. Food Research International, 77(7), 441-449. https://doi.org/10.1016/j.foodres.2015.08.018

Carvalho, K., \& Viera, M. J. (2015). In vitro and in vivo evaluation of the photoprotective and photochemoprotectant potential of the purified fraction of Inga edulis (Master's Dissertation in Pharmaceutical Sciences of Ribeirão Preto of University of São Paulo).

Carvalho, R., Alves, A., Alves, E., Takahashi, J. A., Ferraz, V. P., Porto, A. K., ... Ribeiro, P. R. E. (2015). Fatty acid profile and bioactivity from Annona hypoglauca seeds oil. African Journal of Biotechnology, 14(30), 2377-2382. https://doi.org/10.5897/AJB2015.14714

Christie, W. W. (1989). Gas Chromatography and Lipids-A Practical Guide. The Oily Press, Ayr, Scotland.

Crowley, J. G., \& Fröhlich, A. (1998). Factors affecting the composition and use of Camelina. The Science of Farming and Food, Dublin.

Cruz, M. F., Pereira, G., Ribeiro, M., Da Silva, M. G., Tinoco, L., \& da Silva, B. (2016). Inga saponin, a complex triterpenoid saponin with immunological adjuvant activity from Inga laurina. Carbohydrate Research, 420, 23-31. https://doi.org/10.1016/j.carres.2015.11.008

Dias, L. S., Débor, M. M., Luzia, D. M. M., \& Jorge, N. (2013). Physicochemical and bioactive properties of Hymenaea courbaril L. pulp and seed lipid fraction. Industrial Crops and Products, 49, 610. https://doi.org/ 10.1016/j.indcrop.2013.06.005

Ellman, G. L., Courtney, K. D., Andres, V., \& Featherstone, R. M. (1961). A new and rapid colorimetric determination of acetylcholinesterase. Biochem. Pharmacol., 7(2), 88. https://doi.org/10.1016/0006-2952 (61) $90145-9$

Fernández, I. M., Mozombite, D. M., Santos, R. C., Alves, A., Ribeiro, P. R., Chagas, E. A., ... Maldonado, A. S. (2016). Oil in Inajá Pulp (Maximiliana maripa): Fatty Acid Profile and Anti-acetylcholinestarase Acctivity. 
Orbital: Electron. J. Chem., 8(2), 80-83. https://doi.org/10.17807/orbital.v7i4.769

Flores, E. M., \& Benavides, C. E. (1990). Germinación y morfología de la plántula de Hymenaea courbaril L. (Caesalpinaceae). Rev. Biol. Trop., 38(1), 91-98. Retrieved from http://www.ots.ac.cr/rbt/attachments/ volumes/vol38-1/12_Flores_Hymenaea_courbaril.pdf

Flores, M. E., \& Segura, J. E. (2005). Estructura y función de los receptores acetilcolina de tipo muscarínico y nicotínico. Ver. Mex. Neuroci., 6(4), 315-326. Retrieved from http://www.medigraphic.com/pdfs/ revmexneu/rmn-2005/rmn054f.pdf

Food Ingredients Brasil. (2016). Polyunsaturated Fatty Acids. Food Ingredients Brasil (Vol. 39, pp. 48-56). Retrieved from http://revista-fi.com.br/upload_arquivos/201611/2016110700002001479901769.pdf

Francis, C. M., \& Campbell, M. C. (2003). New high quality oil seed crops for temperate and tropical Australia. A report for the Rural Industries Research and Development Corporation, Australia. Retrieved from http://www.extsoilcrop.colostate.edu/CropVar/documents/oilseeds/alternative_oil/oilseed_crops_for_austral ia.pdf

Franco, A., \& de Faria, S. M. (1997). The contribution of $\mathrm{N}_{2}$-fixing tree legumes to land reclamation and sustainability in the tropics. Soil Biology \& Biochemistry, 29, 897-903. https://doi.org/10.1016/S0038-0717 (96)00229-5

Frank, B., \& Gupta, S. (2005). A Review of Antioxidants and Alzheimer's Disease. Ann. Clin. Psychiatry, 17(4), 269. https://doi.org/10.1080/10401230500296428

Galvão, A. (2005). Plantar árvores para colher o futuro. Projeto Agroecologia na Borborema, Paraíba. Retrieved from http://www.aspta.org.br/wp-content/uploads/2011/11/Cartilha-Plantar-\%C3\%A1rvores-para-colher-ofuturo.pdf

Grossman, J. M., Sheaffer, C., Wyse, D., Bucciarelli, B., Vance, C., \& Graham, P. H. (2006). An assessment of nodulation and nitrogen fixation in inoculated Inga oerstediana, a nitrogen-fixing tree shading organically grown coffee in Chiapas, Mexico. Soil Biology \& Biochemistry, 38, 769-784, https://doi.org/10.1016/ j.soilbio.2005.07.009

Heywood, V. H., Brummitt, R. K., Culham, A., \& Seberg, O. (2007). Flowering plant families of the world (pp. 185-188). Editorial Firefly Books, New York.

Jorge N., \& Luzia, D. M. M. (2012). Characterization of seed oil Pachira aquatica Aublet for food utilization. Acta Amazon, 42, 149-156. https://doi.org/10.1590/S0044-59672012000100017

Kurppa, M., Leblanch, H. A., \& Nygren, P. (2010). Detection of nitrogen transfer from $\mathrm{N}_{2}$-fixing shade trees to cacao saplings in $15 \mathrm{~N}$ labelled soil: Ecological and experimental considerations. Agroforest Syst., 80, 223-239. https://doi.org/10.1007/S10457-010-9327-6

Lorenzi, H. (2002). Brazilian trees. Manual of Identification and Cultivation of Native Arboreal Plants of Brazil (5th ed., Vol. 2). Nova Odesa, São Paulo.

Macedo, M., Freire, M., Franco, O. L., Migliolo, L., \& Oliveira, C. F. (2011). Practical and theoretical characterization of Inga laurina Kunitz inhibitor on the control of Homalinotus coriaceus. Comparative Biochemistry and Physiology, Part B. Biochem. Mol. Biol., 158, 164-172. https://doi.org/10.1016/ j.cbpb.2010.11.005

Macedo, M., Garcia, V. A., Freire, M., \& Richardson, M. (2007). Characterization of a Kunitz trypsin inhibitor with a single disulfide bridge from seeds of Inga laurina (SW.) Willd. Phytochemistry, 68, 1104-1111. https://doi.org/10.1016/j.phytochem.2007.01.024

Macedo, M., Ribeiro, S., Taveira, G., Gomes, V., De Barros, K., \& Maria-Neto, S. (2016). Antimicrobial Activity of ILTI, a Kunitz-Type Trypsin Inhibitor from Inga laurina (SW.) Willd. Curr. Microbiol., 72, 538-544. https://doi.org/10.1007/s00284-015-0970-z

Montandon, G., Silva, A., Carneiro, E., Faria, S., \& Boddey, R. (2010). Nitrogen-fixing legume tree species for the reclamation of severely degraded lands in Brazil. Tree Physiology, 31, 139-149. https://doi.org/ 10.1093/treephys/tpq116

Pakaski, M., \& Kasa, P. (2003). Role of acetylcholinesterase inhibitors in the metabolism of amyloid precursor protein. Curr. Drug Targets CNS Neurol. Disord., 2(3), 163-171. https://doi.org/10.2174/15680070334 82869 
Pelczar, M. J., \& Krieg, N. R. (2010). Microbiologia Conceitos e Aplicações. Pearson Educação do Brasil (2nd ed., Vol. 2, pp. 236-287). São Paulo.

Pennington, T. D. (1997). The genus Inga. Botany (pp. 341-344). The Royal Botanic Gardens, Kew, Foresty Research Programme, Great Britain.

Pompeu, D. R, Rogez, H., Monteiro, K. M., Tinti, S. V., \& Carvalho, J. E. (2012). Antioxidant capacity and pharmacologic screening of crude extracts of Byrsonima crassifolia and Inga edulis leaves. Acta Amazonica, 42(1), 165-172. https://doi.org/10.1590/S0044-59672012000100019

Ramos, V., Cabrera, O., Camargo, E., Ambrósio, A., Vidal, R., da Silva, D., ... Macedo, M. (2012). Molecular cloning and insecticidal effect of Inga laurina trypsin inhibitor on Diatraea saccharalis and Heliothis virescens. Comparative Biochemistry and Physiology Part C: Toxicology \& Pharmacology, 156, 148-158. https://doi.org/10.1016/j.cbpc.2012.07.007

Remigi, P., Zhu, J., Young, J. P., \& Masson-Boivin, C. (2016). Symbiosis within Symbiosis: Evolving Nitrogen-Fixing Legume Symbionts. Trends in Microbiology, 24, 63-75. https://doi.org/10.1016/j.tim.2015. 10.007

Silva, P. S., Nunomura, S. M., \& Nunomura, R. C. (2012). Chemical study on aromas of some Amazonian fruits. II Congresso de Iniciação Científica PIBIC/CNPq-PAIC/FAPEAM, Manaus-AM. Retrieved from http://repositorio.inpa.gov.br/bitstream/123/689/1/Paula\%20Suellen\%20da\%20Paz\%20Silva.pdf

Smith, N., Mori, S. A., Henderson, A., Stevenson, D. W., \& Heald, S. (2004). Flowering Plants of the Neotropics (pp. 151-156). Editorial Princeton, New Jersey.

Soreq, H., \& Seidman, S. (2001). Acetylcholinesterase-New roles for an old actor. Nat. Rev. Neurosci., 2, 294-302. https://doi.org/10.1038/35067589

Sousa, A. L., Silva, J. N., \& Rogez, H. (2010). Purification of phenolic compounds from Inga edulis leaves using solid-phase extraction: Major compounds quantification and antioxidant capacity evaluation. Quim. Nova, 33(1), 38-42. https://doi.org/10.1590/S0100-40422010000100008

Sousa, M. S. (1993). El Genero Inga (Leguminosae: Mimosoideae) Del Sur de Mexico Y Centroamerica, Estudio Previo Para la Flora Mesoamericana. Annals of the Missouri Botanical Garden, 80, 223. https://doi.org/ $10.2307 / 2399826$

Souza, J. N. S, Silva, E. M., Silva, M. N., Arruda, M. S. P., Larondelle, Y., \& Rogez, H. (2007). Identification and Antioxidant Activity of Several Flavonoids of Inga edulis Leaves. J. Braz. Chem. Soc., 18(6), 1276-1280. https://doi.org/10.1590/S0103-50532007000600025

Strayer, D., Belcher, M., Dawson, T., Delaney, B., Fine, J., Flickinger, B., ... Wainwright, B. (2016). Food fats and oils. Institute of Shortening and Edible Oils, Inc. Washington. Retrieved from http://iseo.org/httpdocs/ FoodFatsOils2016.pdf

Tang, L. M., Chen, S. T., \& Lui, T. N. (1994). Citrobacter meningitis in adults. Clin Neurol Neurosurg., 96(1), 52-57. https://doi.org/10.1016/0303-8467(94)90030-2

Trevisan, M. T. S., Macedo, F. V. V., Meent, M. V., Rhee, I. K., \& Verpoorte, R. (2003). Screening for acetylcholinesterase inhibitors from plants to treat Alzheimer's disease. Quím. Nova, $26(3), 301$. https://doi.org/10.1590/S0100-40422003000300002

Vinutha, B., Prashanth, D., Salma, K., Sreeja, S. L., Pratiti, D., Padmaja, R., ... Deepak, M. (2007). Screening of selected Indian medicinal plants for acetylcholinesterase inhibitory activity. J. Ethnopharmacol, 109(2), 359-363. https://doi.org/10.1016/j.jep.2006.06.014

Wang, J. T., Chang, S. C., Chen, Y. C., \& Luh, K. T. J. (2000). Comparison of antimicrobial susceptibility of Citrobacter freundii isolates in two different time periods. Microbiol. Immunol. Infect., 33(4), $258-262$. Retrieved from https://www.ncbi.nlm.nih.gov/pubmed/11269372

\section{Copyrights}

Copyright for this article is retained by the author(s), with first publication rights granted to the journal.

This is an open-access article distributed under the terms and conditions of the Creative Commons Attribution license (http://creativecommons.org/licenses/by/4.0/). 